\title{
Spatiotemporal variability of alkalinity in the Mediterranean Sea
}

\author{
G. Cossarini ${ }^{1}$, P. Lazzari $^{1}$, and C. Solidoro ${ }^{1,2}$ \\ ${ }^{1}$ Istituto Nazionale di Oceanografia e di Geofisica Sperimentale, Sgonico, Trieste, Italy \\ ${ }^{2}$ International Centre for Theoretical Physics, Trieste, Italy \\ Correspondence to: G. Cossarini (gcossarini@ogs.trieste.it) \\ Received: 1 August 2014 - Published in Biogeosciences Discuss.: 3 September 2014 \\ Revised: 28 January 2015 - Accepted: 15 February 2015 - Published: 16 March 2015
}

\begin{abstract}
The paper provides a basin-scale assessment of the spatiotemporal distribution of alkalinity in the Mediterranean Sea. The assessment is made by integrating the available observations into a 3-D transport-biogeochemical model.

The results indicate the presence of complex spatial patterns: a marked west-to-east surface gradient of alkalinity is coupled to secondary negative gradients: (1) from marginal seas (Adriatic and Aegean Sea) to the eastern Mediterranean Sea and (2) from north to south in the western region. The west-east gradient is related to the mixing of Atlantic water entering from the Strait of Gibraltar with the high-alkaline water of the eastern sub-basins, which is correlated to the positive surface flux of evaporation minus precipitation. The north-to-south gradients are related to the terrestrial input and to the input of the Black Sea water through the Dardanelles. In the surface layers, alkalinity has a relevant seasonal cycle (up to $40 \mu \mathrm{mol} \mathrm{kg}{ }^{-1}$ ) that is driven by physical processes (seasonal cycle of evaporation and vertical mixing) and, to a minor extent, by biological processes. A comparison of alkalinity vs. salinity indicates that different regions present different relationships: in regions of freshwater influence, the two quantities are negatively correlated due to riverine alkalinity input, whereas they are positively correlated in open sea areas of the Mediterranean Sea.
\end{abstract}

\section{Introduction}

The dissolution of atmospheric $\mathrm{CO}_{2}$ mitigates the effects of the atmospheric concentration of fossil carbon emissions but causes acidification in marine water. Observations of ocean acidification have already been recorded, and evidence suggests that this phenomenon is occurring at an unprecedented rate. A number of studies indicate that ocean acidification might impact the structure and functioning of ecological systems, with cascading consequences on socio-economic activities (Rodrigues et al., 2013; Turley and Boot, 2011; Melaku Canu et al., 2015). In this context alkalinity is a very relevant concept, because it is a measure of the capabilities of sea water to buffer acidification. In fact, a number of chemical compounds are dissolved in sea water, including carbonate and bicarbonate ions, boron and other weak bases, which can combine with free protons. Total alkalinity is operationally defined as the sum of these weak bases (Zeebe and Wolf-Gladrow, 2001), and empirically measured as the amount of protons buffered by seawater up to a reference $\mathrm{pH}$ level. Therefore, different regional seas present different responses to ocean acidification also as a consequence of specific alkalinity conditions, a fact that might call for specific studies. As an example, in the Mediterranean Sea - a landlocked, relatively small, highly dynamic ecosystem with high anthropic pressure in the coastal areas - the existing data indicate that alkalinity is significantly higher than in the Atlantic Ocean, and that a west-east spatial gradient is present. Thus, the alkalinity concentration increases moving from the Atlantic Ocean to the western basin of the Mediterranean and reaches its maximum values in the eastern basin (Schneider et al., 2007; Touratier and Goyet, 2011; Alvarez et al., 2014). This pattern clearly indicates that it is not possible to address the study of this basin by relying only on the results of global studies.

Global climatology has been produced for $\mathrm{pH}$ and alkalinity (Lee et al., 2006; Takahashi et al., 2014), often based on the use of empirical site-specific regressions between alkalinity and temperature and salinity data. In the open sea environment, alkalinity often correlates with salinity and temperature (Lee et al., 2006; Takahashi et al., 2014). The underpinning process is that evaporation (precipitation) concen- 
trates (dilutes) all compounds that contribute to alkalinity. The regression coefficients, however, change with the nature and relative composition of these compounds and can vary over different regions. Furthermore, salinity cannot track the occurrence of biological processes that also modify alkalinity, such as nutrients uptake, mineralization, nitrification and denitrification (Wolf-Gladrow et al., 2007). Nonetheless, salinity-based empirical relationships are widely used to reconstruct the spatiotemporal distribution of alkalinity from existing data sets and to infer conclusions on $\mathrm{pH}$ state and trends.

Several regression relationships have been proposed for the Mediterranean Sea (Schneider et al., 2007; CopinMontégut, 1993) and indicate different reconstructions. In addition, regressions based on local areas exist (SantanaCasiano et al., 2002; Huertas et al., 2009), some of which indicate a negative correlation between alkalinity and salinity in regions of freshwater (river) input (Luchetta et al., 2010). Few data, however, are available for the Mediterranean Sea, and as such, in this important basin the statistical spatial interpolation and extrapolation of existing information are critical.

Process-based numerical models represent an alternative to the use of empirical regressive models. In process-based numerical models, alkalinity and dissolved inorganic carbon (DIC) are considered explicit state variables (master variables used to solve the carbonate system) that are transported by physical processes and modified by chemical and biological processes (Wakelin et al., 2012; Prowe et al., 2009; Artioli et al., 2012; Turi et al., 2014; Fiechter et al., 2014). Also, this approach is not free from deficiencies, as it implies the need to explicitly parameterize the major known relationships among DIC, alkalinity and the biogeochemical processes, and to define exactly which chemical compounds are considered in the definition of the alkalinity. The boundary and initial conditions of the area considered must be estimated as well. The advantage of this approach is that once a numerical model exists, it can be used to interpolate existing observations and to make projections on future states.

Many studies were carried out to numerically simulate the carbonate system in the global oceans (Orr et al., 2005). In the Mediterranean Sea, box modelling estimates were made by d'Ortenzio et al. (2008), who used an array of decoupled 1-D water column biogeochemical models forced by satellite observations, and by Louanchi et al. (2009), who used a coupled data-diagnostic model approach to estimate trends in carbonate variables over the last decades. A high-resolution circulation model coupled with $\mathrm{CO}_{2}$ module adopting a perturbation technique was used by Palmiéri et al. (2014) to estimate the anthropogenic $\mathrm{CO}_{2}$ in the Mediterranean Sea. However, in all these publications, alkalinity was derived from a salinity regression, in agreement with Schneider et al. (2007). In contrast, in this manuscript, we dynamically simulated alkalinity by introducing a new full state variable into an existing state-of-the-art biogeochemical model of the
Mediterranean Sea (Lazzari et al., 2012). We also use the extended model to integrate, in a coherent framework, the available measures of alkalinity within the Mediterranean Sea and along its boundaries with the aim of deriving a spatiotemporal climatology of alkalinity. The model results are then used to explore the spatiotemporal variability of this important parameter and assess specific relationships between alkalinity and salinity for different regions of the Mediterranean Sea. The impact of different processes, like biological uptake, on alkalinity spatial and temporal variability is also addressed.

\section{Model and data for the Mediterranean Sea}

\subsection{Biogeochemical and carbonate system coupled model}

The model used in the present study is the 3-D Océan PArallélisé Transport Model coupled with the Biogeochemical Flux Model (OPATM-BFM). It is capable of resolving the large-scale variability and seasonal cycle of nutrients and primary producers (Lazzari et al., 2012).

The transport of dissolved and particulate matter is resolved using the OPATM transport model (Lazzari et al., 2010) offline forced by the dynamical fields that are produced by the MED16 Ocean General Circulation Model (OGCM) (Béranger et al., 2005).

The transport is computed with a horizontal resolution of $1 / 8^{\circ}$ (approximately $12 \mathrm{~km}$ ) and with a vertical $z$ coordinate discretization that is coarser at the bottom layers and more refined at the surface layers (13 levels in the $0-200 \mathrm{~m}$ layer, 7 layers in the 200-600 m layer and 23 levels in the 600bottom layer).

The dynamics of the biogeochemical properties are described by the BFM model (http://bfm-community.eu), a biogeochemical model that describes the cycles of nitrogen, phosphorus, silica and carbon through biotic (four phytoplankton, two microzooplankton and two mesozooplankton pools, heterotrophic bacteria) and abiotic (detritus, labile, semi-labile and refractory dissolved organic matter, dissolved inorganic compounds) components as a function of temperature and light (Lazzari et al., 2012).

The OPATM-BFM was upgraded by implementing a carbonate system module that requires two new state variables: dissolved inorganic carbon (DIC) and alkalinity.

Alkalinity evolution is driven by physical and biological mediated processes and boundary conditions fluxes:

$$
\frac{\partial \mathrm{ALK}}{\partial t}=\left.\frac{\partial \mathrm{ALK}}{\partial t}\right|_{\text {bio }}+\left.\frac{\partial \mathrm{ALK}}{\partial t}\right|_{\text {trsp }}+\left.\frac{\partial \mathrm{ALK}}{\partial t}\right|_{\mathrm{EmP}} .
$$

In particular, according to its explicit conservative expression (Wolf-Gladrow et al., 2007), the total alkalinity dynamic is affected by the biological processes that alter the concentrations of $\mathrm{NO}_{3}^{-}, \mathrm{PO}_{4}^{3-}$ and $\mathrm{NH}_{4}^{+}$("bio" term in Eq. 1). Nitrification, $\mathrm{NH}_{4}^{+}$uptake and the release of both $\mathrm{NO}_{3}^{-}$and $\mathrm{PO}_{4}^{3-}$ 
Table 1. List of available alkalinity data sets for the Mediterranean Sea.

\begin{tabular}{|c|c|c|c|}
\hline Name & Area & Period & Reference \\
\hline Meteor51/2 & Mediterranean Sea & June 2001 & Schneider et al. (2007) \\
\hline Meteor84 & Mediterranean Sea & April 2011 & Tanhua et al. (2012) \\
\hline Prosope & $\begin{array}{l}\text { Western Mediterranean } \\
\text { and Ionian Sea }\end{array}$ & 1999 & Bégovic and Copin (2013) \\
\hline Boum2008 & Mediterranean Sea & June-July 2008 & Touratier et al. (2012) \\
\hline Sesame Egeo & Aegean Sea & April, September 2008 & http://isramar.ocean.org.il/PERSEUS_Data \\
\hline $\begin{array}{l}\text { Sesame Regina Maris } \\
\text { Sesame Garcia del cid }\end{array}$ & Alboran Sea & April, September 2008 & http://isramar.ocean.org.il/PERSEUS_Data \\
\hline Sesame Adriatic & $\begin{array}{l}\text { Adriatic and northern } \\
\text { Ionian Sea }\end{array}$ & April, October 2008 & http://isramar.ocean.org.il/PERSEUS_Data \\
\hline CARBGIB 1-6 & Strait of Gibraltar, Alboran Sea & $2005-2006$ & Huertas (2007a) \\
\hline GIFT1-2 & Strait of Gibraltar, Alboran Sea & $2005-2006$ & Huertas (2007b) \\
\hline Dyfamed & Gulf of Lion & $2001-2005$ & Copin-Montégut and Bégovic (2002) \\
\hline
\end{tabular}

by the phytoplankton and bacterial groups decrease alkalinity by an equivalent amount of moles. On the other hand, the uptake of $\mathrm{NO}_{3}^{-}$and $\mathrm{PO}_{4}^{3-}$ and the $\mathrm{NH}_{4}^{+}$release by phytoplankton and bacteria and the denitrification increase alkalinity (Wolf-Gladrow et al., 2007). The evaporation minus precipitation flux at the surface affects alkalinity by producing either a concentration or a dilution ("EmP" term in Eq. 1). Alkalinity is then advected and diffused by the tracer transport model, which integrates the exchanges with Atlantic buffer and the input from river discharges ("trsp" term in Eq. 1).

In turn, alkalinity - together with DIC and temperature determines seawater $\mathrm{pH}$, dissolved $\mathrm{CO}_{2}\left(p \mathrm{CO}_{2}\right)$ and, eventually, DIC exchange at the air-sea interface (Orr et al., 1999).

\subsection{Model setup}

The present run covers the 1998-2004 period; the physical and biogeochemical setups are extensively detailed by Béranger et al. (2005) and Lazzari et al. (2012) and are briefly reported here. The atmospheric forcings are from the ERA40 reanalysis (Uppala et al., 2005), and from the ECMWF analysis. Net evaporation $\left(0.7 \mathrm{~m} \mathrm{yr}^{-1}\right)$ and water balance considering fluxes at the Strait of Gibraltar are consistent with current knowledge (Béranger et al., 2005). The initial conditions of physical variables are based on the MODB4 climatology (Brankart and Brasseur, 1998), and those of the nutrients are based on the MEDAR/MEDATLAS ${ }^{1}$ data sets (Crise et al., 2003). The nutrient loads (nitrates, phosphates and silicates) are from the terrestrial inputs derived from the paper of Ludwig et

\footnotetext{
${ }^{1}$ MEditerranean Data Archaeology and Rescue/MEDiterranean ATLAS
}

al. (2009). The atmospheric inputs of phosphates and nitrates are also included, considering a mean annual value for the eastern and western Mediterranean Sea (Ribera d'Alcalà et al., 2003). A buffer area in the Atlantic Ocean is used to simulate the boundary at the Strait of Gibraltar, as detailed by Béranger et al. (2005) and Lazzari et al. (2012).

Regarding alkalinity and DIC, three mean profiles are computed from data of the Meteor51/2 cruise (Schneider et al., 2007) and used to uniformly initialize the western Mediterranean Sea (alb, nwm, sww, swe and tyr sub-basins in Fig. 1), Ionian/Adriatic seas (ion, adn and ads in Fig. 1) and Levantine sub-basin (lev in Fig. 1). The Aegean Sea (aeg) is initialized with a mean profile that is computed from the Sesame Aegean data set (Table 1). A Newtonian dumping term regulates the Atlantic buffer zone that is outside the Strait of Gibraltar (atl in Fig. 1), where the alkalinity and DIC concentrations are relaxed to the mean profiles derived from the data published by Huertas et al. (2009) and Dafner et al. (2001).

The terrestrial inputs of alkalinity are computed as the products of freshwater flows, as given by Ludwig et al. (2009), and the terrestrial concentration of alkalinity per water mass, estimated from each of the 10 macro-coastal sectors used by Ludwig et al. (2009), based on previously obtained data (Copin-Montégut, 1993). Table 2 reports the mean alkalinity values at the macro-coastal areas and the annual loads, including the quota of the most relevant rivers. The Dardanelles inputs are considered in the same way but based on earlier information (Somot et al., 2008; CopinMontégut, 1993). Atmospheric $\mathrm{CO}_{2}$ is set according to the trend shown at the Lampedusa station (Artuso et al., 2009). 
Table 2. Alkalinity mean annual discharges for the Mediterranean sub-basins and quota of the discharges due to major rivers (second column). Values of alkalinity concentration in the terrestrial input of the given sub-basins (third column) are derived from Copin-Montégut (1993).

\begin{tabular}{|c|c|c|}
\hline Sub-basins and major rivers & $\begin{array}{l}\text { Alkalinity } \\
\text { discharges } \\
{\left[\mathrm{Gmol} \mathrm{yr}^{-1}\right]}\end{array}$ & $\begin{array}{l}\text { Alkalinity } \\
\text { concentration } \\
{\left[\mathrm{mmol} \mathrm{m}^{-3}\right]}\end{array}$ \\
\hline Alboran (alb) & 12 & 2960 \\
\hline $\begin{array}{l}\text { South-west west (sww) and } \\
\text { south-west east (swe) }\end{array}$ & 23 & 2960 \\
\hline $\begin{array}{c}\text { North-west Mediterranean (nwm) } \\
\text { Ebro } \\
\text { Rhone }\end{array}$ & $\begin{array}{l}251 \\
31 \\
163\end{array}$ & 2960 \\
\hline Tyrrhenian Sea (tyr) & 104 & 5675 \\
\hline $\begin{array}{l}\text { Northern Adriatic Sea (adn) and } \\
\text { southern Adriatic Sea (ads) } \\
\text { Po }\end{array}$ & $\begin{array}{l}319 \\
182\end{array}$ & 2700 \\
\hline Ionian Sea (ion) & 36 & 2200 \\
\hline Aegean Sea (aeg) & $\begin{array}{l}1265 \\
1150\end{array}$ & 2620 \\
\hline $\begin{array}{l}\text { Levantine (lev) sub-basin } \\
\text { Nile }\end{array}$ & $\begin{array}{l}79 \\
32\end{array}$ & 2200 \\
\hline
\end{tabular}

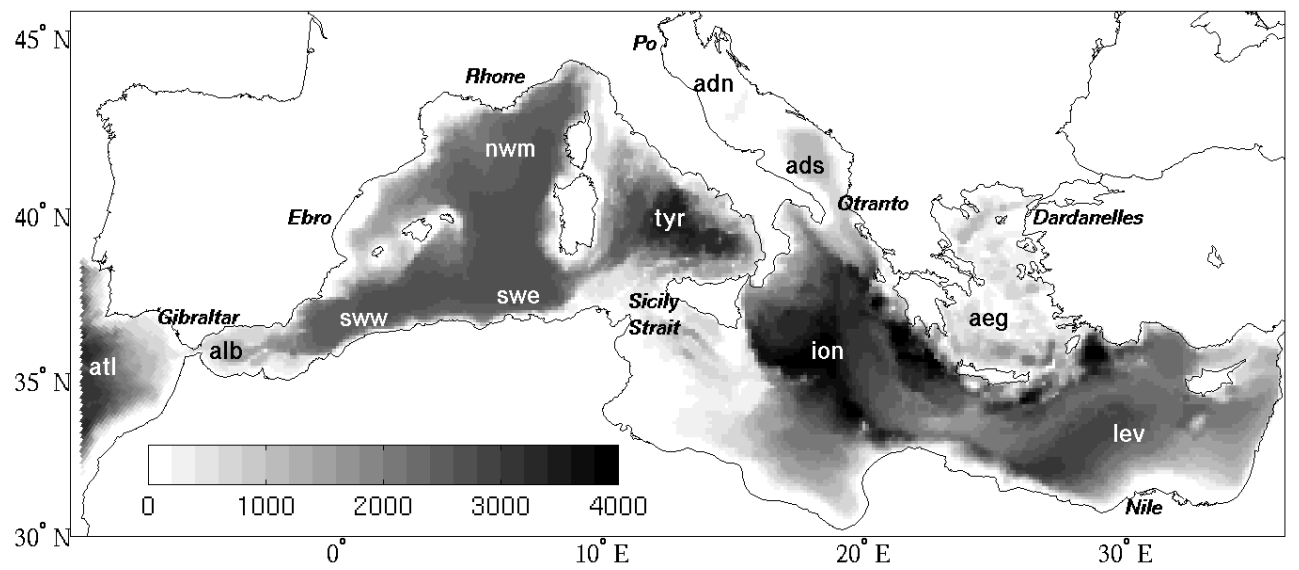

Figure 1. Map of the Mediterranean Sea domain reporting the sub-basins indication (atl, Atlantic buffer zone; alb, Alboran Sea; nwm, north-west Mediterranean; sww, south-west west; swe, south-west east; tyr, Tyrrhenian Sea; ion, Ionian Sea; adn, northern Adriatic Sea; ads, southern Adriatic Sea; aeg, Aegean Sea; lev, Levantine sub-basin), the location of principal rivers and straits.

To smooth artificial effects of discontinuous initial conditions, before starting the actual biogeochemical simulation a spin-up period ( 5 years) was run by using atmospheric forcing typical of the period.

\subsection{Reference data set for comparison}

A reference data set of alkalinity observations (Table 1) has been gathered for model initialization and validation. More than 4200 alkalinity measurements, collected through Pangea, SeaDataNet and Perseus database services, refer to several campaigns and research cruises (Table 1) in the period 1999-2011. This period is consistent with the time window of the simulation and allows one to avoid possible problems of inconsistency with older data (Louanchi et al., 2009). Given the inhomogeneity of the spatiotemporal coverage of data, average climatology profiles have been computed for a grid of $1^{\circ} \times 1^{\circ}$ for the year and the four seasons. The $1^{\circ} \times 1^{\circ}$ bins at any given quota are considered empty when less than four measurements were present, or when the range of variability of the data was larger than $40 \%$. 

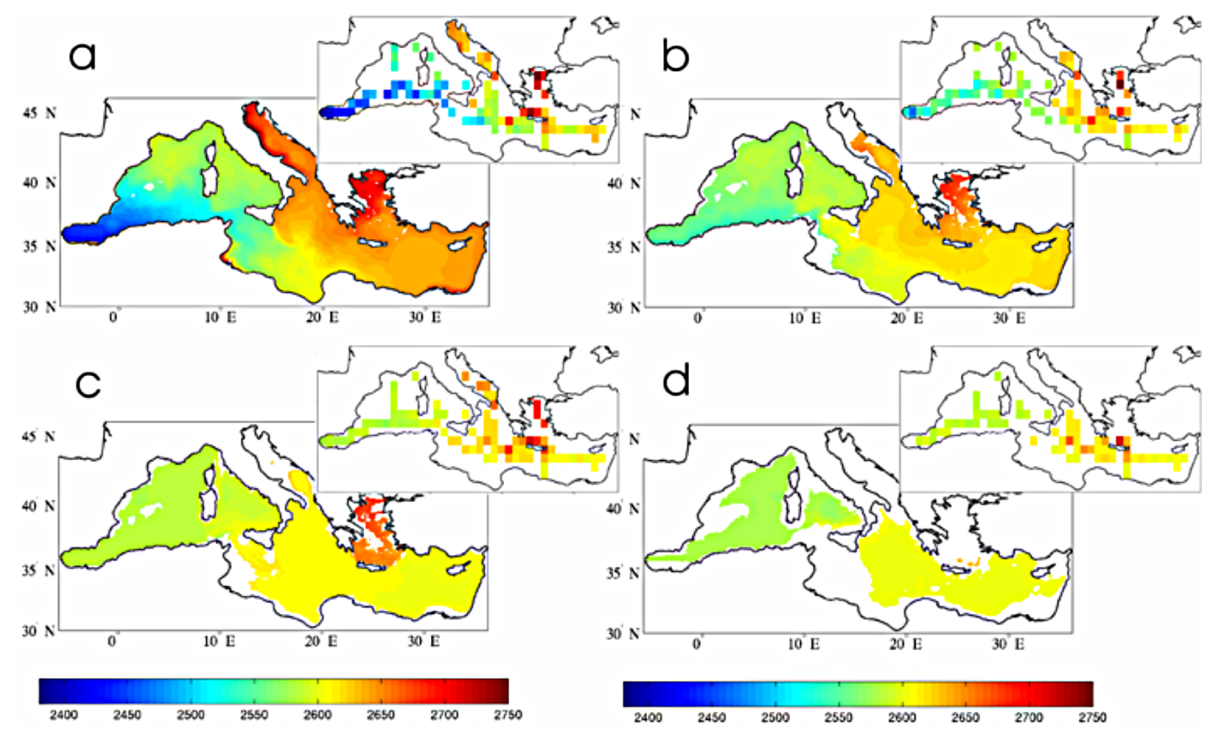

Figure 2. Alkalinity maps for selected layers: surface (a), 100-200 m (b), 400-1500 m (c) and 1500-4000 (d). Model maps refer to the average of the simulation. Maps of $1^{\circ} \times 1^{\circ}$ annual climatology are reported in the upper right corner of each selected layer.

\section{Results and discussion}

\subsection{Spatial variability of alkalinity}

The physical and biogeochemical results of the present simulation have been extensively presented and validated by Béranger et al. (2005) and Lazzari et al. (2012), respectively. Here, we focus on the alkalinity time and space variability in the Mediterranean Basin. The results show that the Mediterranean Sea is characterized by alkalinity values that are much higher (100-150 $\mu \mathrm{mol} \mathrm{kg}{ }^{-1}$ higher) than those observed in the Atlantic Ocean at the same latitude (Lee et al., 2006). The results indicate a strong surface west-to-east gradient (Fig. 2a), with values ranging from $2400 \mu \mathrm{mol} \mathrm{kg}-1$ near the Strait of Gibraltar to $2700 \mu \mathrm{mol} \mathrm{kg} \mathrm{k}^{-1}$, as simulated in the upper ends of the eastern marginal seas (Adriatic and Aegean seas). These features are in agreement with the recent experimental findings (Schneider et al., 2007; Touratier and Goyet, 2011; Alvarez et al., 2014). The west-to-east gradient is a permanent structure recognizable at all depths, but less marked in the maps of the intermediate and deep layers (Fig. 2). Indeed, the range of variability of alkalinity for the deepest layer spans from $2560 \mu \mathrm{mol} \mathrm{kg}^{-1}$ in the Alboran Sea to $2620 \mu \mathrm{mol} \mathrm{kg}{ }^{-1}$ in the Levantine sub-basin (2650-2670 $\mu \mathrm{mol} \mathrm{kg}^{-1}$ in the deeper layers of the Adriatic and Aegean seas). At the surface, alkalinity dynamics are driven by three major factors: the input in the eastern marginal seas (the terrestrial input from the Po and other Italian rivers and the input from the Dardanelles, see Table 2), the effect of evaporation in the eastern basin and the influx of the low-alkaline Atlantic water. The thermohaline basin-wide circulation modulates the intensity and the patterns of the spatial gradients. Intermediate and deep layers show lower dynamics and less variability. The Adriatic and Aegean seas recharge the Levantine intermediate and deep waters as is shown by the calculated fluxes at the boundaries of these sub-basins. On average, the Otranto Strait accounts for a northward flux of $8.18 \times 10^{12} \mathrm{~mol} \mathrm{yr}^{-1}$ at the surface $(0-200 \mathrm{~m})$ and a southward flux of $8.21 \times 10^{12} \mathrm{~mol} \mathrm{yr}^{-1}$ at the intermediate and deep layers. The Aegean Sea imports $35.9 \times 10^{12} \mathrm{~mol} \mathrm{yr}^{-1}$ from the eastern Mediterranean Sea at the $0-200 \mathrm{~m}$, layer but it exports $36.5 \times 10^{12} \mathrm{~mol} \mathrm{yr}^{-1}$ to the intermediate and deep layers of Levantine and Ionian subbasins.

The excess of alkalinity in the intermediate and deep layers of the eastern sub-basins is then spread towards the western sub-basins by the thermohaline Mediterranean circulation. At the Strait of Sicily, the eastward surface flux (0$200 \mathrm{~m}$ ) of $48.3 \times 10^{12} \mathrm{~mol} \mathrm{yr}^{-1}$ is more than counterbalanced by a westward flux of $56.9 \times 10^{12} \mathrm{~mol} \mathrm{yr}^{-1}$ at the intermediate and deep layers, which results consistent with the spreading of the Levantine Intermediate Water described by Alvarez et al. (2014).

The model reconstructions of horizontal gradients at the different depths are quite consistent with the reference values (Fig. 2). High correlation values and low relative root mean square error values (depicted in the Taylor diagram of Fig. 3) quantitatively confirm the good performance of the model in reproducing the mean annual fields. Higher relative errors (normalized bias and RMSE) are registered at the deepest layers (Fig. 2d and symbol (e) in Fig. 3), where the effect of input of high-alkaline water from the Aegean and Adriatic seas to the Ionian Sea and to the Levantine regions appears to be partly underestimated. However, considering the absolute values, the bias and RMSE are quite low: 10.4 and $14.6 \mu \mathrm{mol} \mathrm{kg}{ }^{-1}$, respectively. These values are signifi- 
Table 3. Coefficients of the alkalinity vs. salinity linear regression of the surface layer (mean 0-50 m) computed for the model results (year and seasonal averages) and for observations of data set listed in Table 1. Coefficients of Schneider et al. (2007) regression are also reported.

\begin{tabular}{lcccccc}
\hline Alk $=a \cdot$ Sal $+b$ & $a$ & $b$ & $R^{2}$ & RMS(resid) & n.data & $p$ \\
\hline Model, mean layer 0-50 m, year & $85.5( \pm 4.9)$ & $-664.6( \pm 186.2)$ & 0.91 & 18.8 & $>5000$ & $<0.001$ \\
\hline $\begin{array}{l}\text { Observations of Table 2 data sets, } \\
\text { mean layer 0-50 m }\end{array}$ & $88.7( \pm 7.5)$ & $-834.5( \pm 282.5)$ & 0.90 & 27.7 & 198 & $<0.001$ \\
\hline $\begin{array}{l}\text { Schneider et al. (2007), } \\
\text { observations of Meteor51/2 }\end{array}$ & $73.7( \pm 3.0)$ & $-285.7( \pm 114.9)$ & 0.98 & 8.2 & 15 & \\
\hline Model, mean layer 0-50 m, winter & $83.1( \pm 3.8)$ & $-582.8( \pm 145.1)$ & 0.94 & 13.7 & $>5000$ & $<0.001$ \\
\hline Model, mean layer 0-50 m, spring & $81.7( \pm 4.3)$ & $-528.9( \pm 163.1)$ & 0.93 & 16.5 & $>5000$ & $<0.001$ \\
\hline Model, mean layer 0-50 m, summer & $85.0( \pm 5.8)$ & $-648.2( \pm 223.2)$ & 0.88 & 24.1 & $>5000$ & $<0.001$ \\
\hline $\begin{array}{l}\text { Model, mean layer 0-50 m, autumn } \\
86.4( \pm 5.7)\end{array}$ & $-701.9( \pm 219.5)$ & 0.89 & 22.5 & $>5000$ & $<0.001$ \\
\hline
\end{tabular}

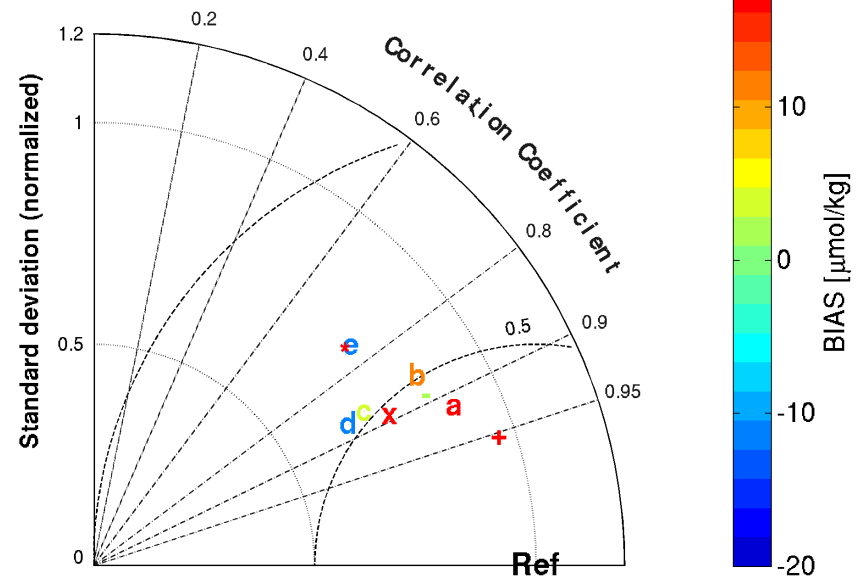

Figure 3. Taylor diagram of alkalinity of the mean annual model and observation fields for the following layers: surface (a), 50$100 \mathrm{~m}$ (b), 100-200 m (c), 200-1500 m (d) and 1500-4000 m (e) and for the following seasons at the surface layer: winter $(+)$, spring (-) summer (x) and autumn (*). The colour of the symbols and the bar report the bias (mean model-observation error).

cant only because of the low variability in this layer (standard deviation equals to $15.8 \mu \mathrm{mol} \mathrm{kg}{ }^{-1}$ ). The bias error is relatively low for all the layers except for the surface one. The model performance at the surface is worsened by an overestimation of values (about $20 \mu \mathrm{mol} \mathrm{kg}{ }^{-1}$ ) in the Ionian and western part of Levantine sub-basins.

\subsection{Alkalinity vs. salinity regression}

It has been recognized that several different relationships between alkalinity and salinity are appropriate for different sub-basins of the Mediterranean Sea, given the different sources of alkalinity and water mass dynamics (Schneider et al., 2007; Touratier and Goyet, 2011; Luchetta et al., 2010). The results of the present simulation allow for the basin-wide quantification of these regressions and for the investigation of the rationale of their differences (Fig. 4).

The relationship computed using the model grid points of the pelagic areas (profiles with depths greater than $200 \mathrm{~m}$ ) is somehow consistent with the one computed on observations (Table 3), and supports the conclusion that at a basin scale, the effect of evaporation and the end term of Atlantic water are the major drivers for alkalinity spatial dynamics. However, a close analysis reveals that the Mediterranean regression is the average of several regressions: one computed for the eastern sub-basins (ion and lev), a second one computed for the western sub-basins (alb, tyr, sww and swe) and two more for the eastern marginal seas (Adriatic and Aegean seas). Results, therefore, highlight that the two main subbasins are affected by different sources of interference. The western regression has higher correlation and lower dispersion values for residuals and lower regression coefficient values compared with the eastern sub-basin. Therefore, the latter is characterized by the presence of more intense sources of variability. Negative correlations between salinity and alkalinity are observed in the marginal seas, where the changes in salinity no longer can be related to evaporation processes, but they track the input of alkalinity at zero or low salinity from rivers and the Dardanelles. The Adriatic Sea regression shows the highest dispersion in coefficient values and error of residuals as a consequence of the higher variability generated by the local and topographic effects. Further, for the nwm sub-basin, the effect of inputs from the Rhone and Ebro rivers generates a negative correlation, but this effect remains confined only in the Gulf of Lion. Other local effects can produce deviations from the general relationship, as for example, the coastal areas of the Gulf of Gabes and the far eastern coastal areas of the Levantine sub-basin, where local sources of terrestrial inputs are associated with high rates of evaporation flux and thus, in Fig. 4, produce the orange and red 


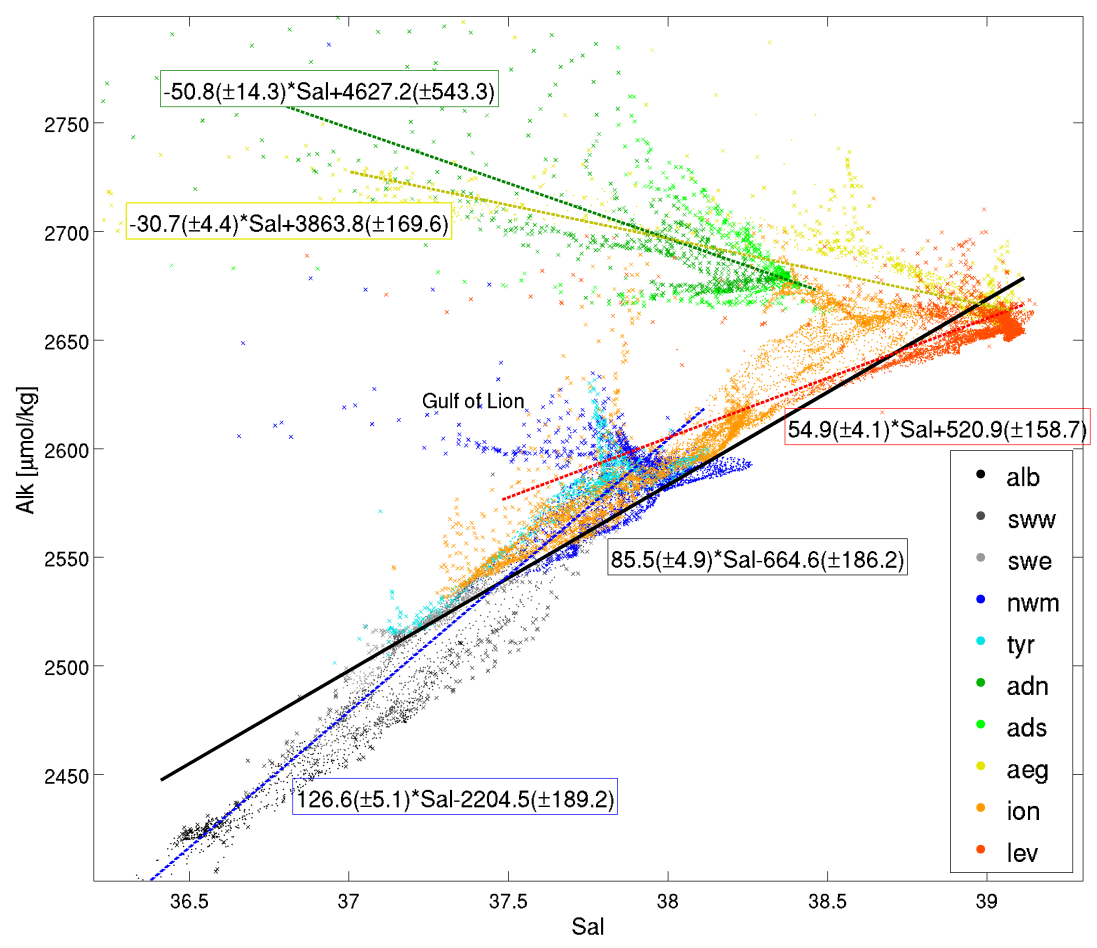

Figure 4. Regressions between salinity and alkalinity at the surface. Coloured points belong to the different sub-basins of Fig. 1. The regression for the whole Mediterranean Sea is shown as a black solid line, and the equation is reported in the black box ( $95 \%$ confidence intervals of the coefficients are in brackets; $p<0.001 ; R^{2}=0.91$; RME $=18.8$ ). The regression uses data from the alb, sww, swe, tyr, ion and lev sub-basins with depths greater than $200 \mathrm{~m}$. Sub-basin regressions are computed for the Adriatic sea (green box and line; data from adn and ads; $R^{2}=0.45$, RMSE $=32.0$ ), the Aegean Sea (yellow box and line, data from aeg; $R^{2}=0.77, \mathrm{RMSE}=9.3$ ), the western Mediterranean Sea (blue box and line; data from alb, sww, swe and tyr with depths greater than $200 \mathrm{~m} ; R^{2}=0.95$, RMSE $=11.6$ ) and the eastern Mediterranean Sea (red box and line; data from ion and lev with depths greater than $200 \mathrm{~m} ; R^{2}=0.74, \mathrm{RMSE}=13.8$ ).

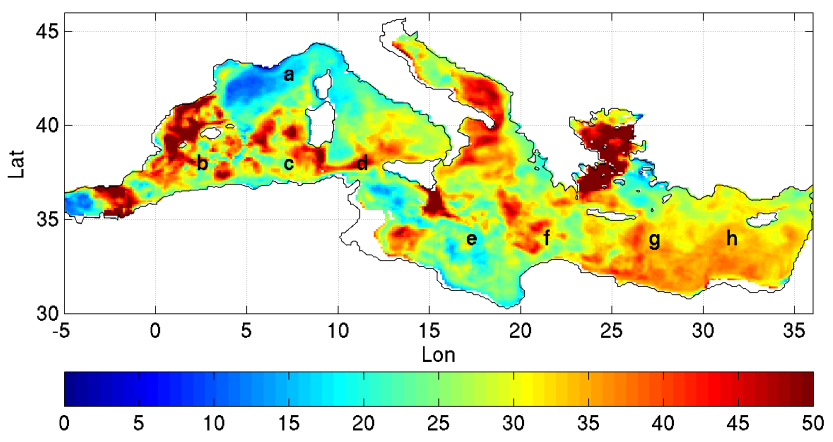

Figure 5. Map of the mean annual range of alkalinity for the surface layer $(0-50 \mathrm{~m})$. Letters indicate the coordinates of the profiles given in Fig. 6.

clusters lying above the Mediterranean Sea regression (black solid line).

Our regressions update the findings of Schneider et al. (2007). The steeper slopes and the more negative intercepts of our regressions reflects the fact that our data cover the whole Mediterranean basin from Gibraltar to the end of Levantine sub-basin. Differences between our model and ob- servation regressions are not statistically significant, but the lower slope of the model regression likely reflects the model overestimation of Ionian points (Fig. 2). Given the relative weight of this sub-basin in relation to the total number of grid points of the Mediterranean domain, the Ionian model overestimation, indeed, causes the raise of the lower left end of the regression line (Fig. 4). Seasonal variability of the basinwide regression leads to an uncertainty of the slope and intercept estimates of about 6 and $30 \%$, respectively (Table 3 ). The slope increases during summer and decreases during winter (Table 3) reflecting the differential impact of different factors in the different sub-basins throughout the year.

\subsection{Temporal variability of alkalinity}

A marked seasonal cycle is simulated in the surface layer (Fig. 5): the range of the mean annual variation of surface alkalinity varies from approximately $10-15 \mu \mathrm{mol} \mathrm{kg}^{-1}$ for the Alboran and the north-western regions to up to $50 \mu \mathrm{mol} \mathrm{kg}-1$ in the Balearic region, in the Aegean Sea, in patches of the southern western region and in the Strait of Sicily. The extent of seasonal variability is consistent with available observations, as shown by the high values of the skill indexes 

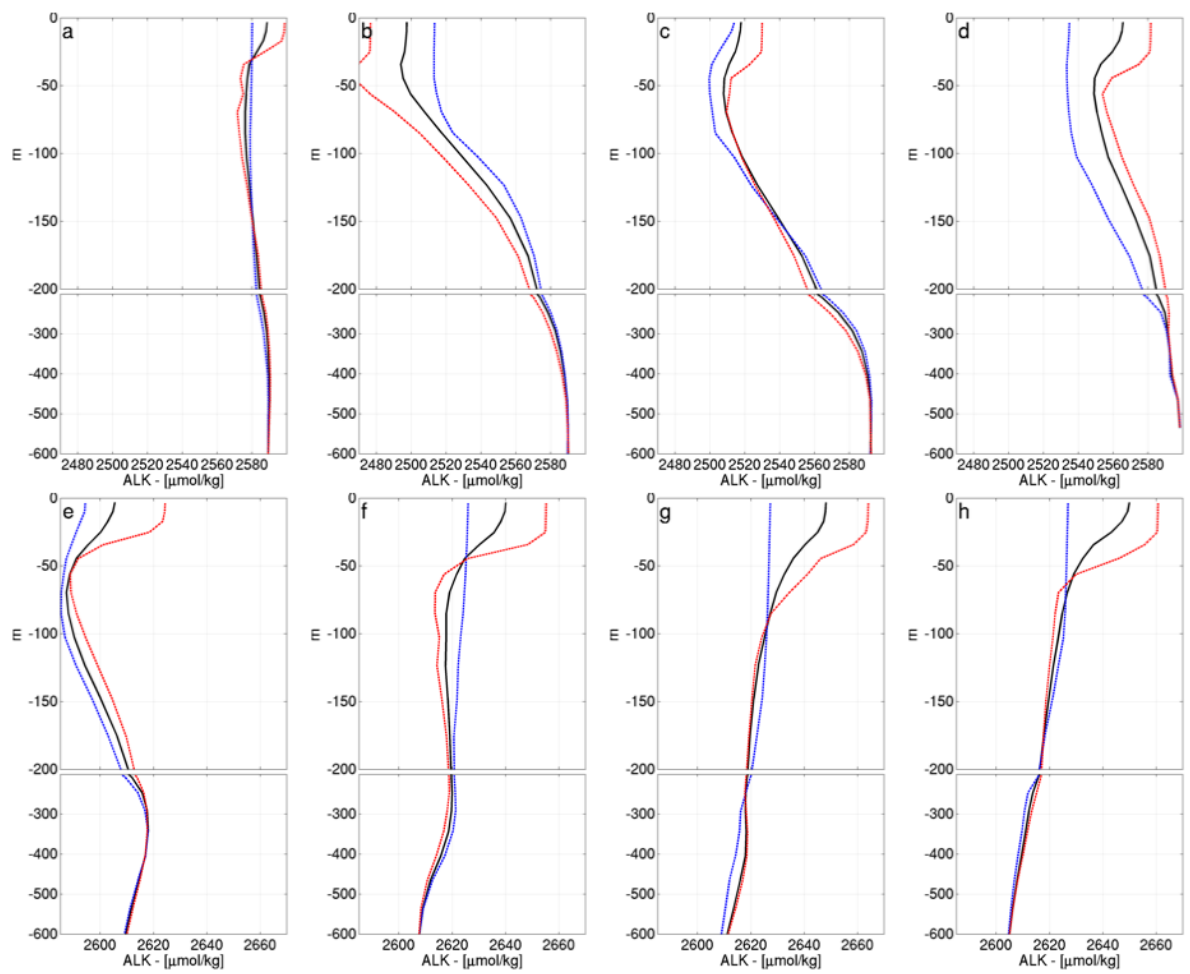

Figure 6. Mean annual vertical profiles of alkalinity (black line) in selected points of the Mediterranean Sea (points in Fig. 5). Mean annual range of variability between winter (blue line) and summer (red line) profiles.

depicted in the Taylor diagram for the seasonal comparison (symbols in Fig. 3). Vertical profiles (Fig. 6) are generally characterized by large variability at the surface, minimum values between the surface and $100 \mathrm{~m}$, a sharp increase until 200-250 $\mathrm{m}$ and almost stationary values below $400-500 \mathrm{~m}$ (Fig. 5), but important differences between the eastern and western profiles highlight the presence of different forcings, water mass dynamics and confinements in each area.

The largest fluctuations are observed in the transition areas between different sub-basins, where the surface circulation modifies the patterns of the horizontal gradients throughout the year (e.g. Balearic area, edges of the Strait of Sicily and northern and eastern Ionian Sea, Fig. 5). On the other hand, mesoscale dynamics and horizontal transport of the low-alkaline Atlantic water generates the patches of large annual fluctuations in the south-western Mediterranean Sea (Fig. 5). These large fluctuations are mainly confined to the first $50 \mathrm{~m}$ of the water column (Fig. 6b, d-f). A large annual variability is simulated for the southern and central Aegean Sea, where the influence of the Dardanelles boundary and of seasonal cycle of surface enrichment and mixing is significant.

In the western Mediterranean Sea, two areas are characterized by a low range $\left(15-20 \mu \mathrm{mol} \mathrm{kg}{ }^{-1}\right)$ of the annual cycle at the surface: the Alboran and the north-western sub-basins. In the first area, the impact of the constant boundary conditions at the Atlantic boundary buffer area limits the seasonal oscillation. In the second area, a high vertical ventilation causes an exceeding vertical homogenization of the water column below 20-30 m throughout the year (Fig. 6a): the lower limit of the range of the graph at the surface (blue line in Fig. 6a) has values of $2580 \mu \mathrm{mol} \mathrm{kg}{ }^{-1}$, which seems to be an overestimation with respect to the lower limit of observations at the Dyfamed station reported by Copin-Montègut and Begovic (2002).

In the south-west Mediterranean Sea (Fig. 6c, d), the mixing of Levantine water (below $400 \mathrm{~m}$ ) and Atlantic water (upper layer) generates a zone (between 150 and $400 \mathrm{~m}$ ) that is characterized by large temporal variability. Moving eastward, to points e and f of Fig. 6, the modified Atlantic water generates a minimum at $50-100 \mathrm{~m}$ in summer, when evaporation produces a surface lens of high-alkaline concentration (red lines in Fig. 6). During winter the profiles tend to be more homogeneous (blue lines in Fig. 6). Below the modified Atlantic water, the intermediate Levantine water, characterized by alkalinity values of $2610-2620 \mu \mathrm{mol} \mathrm{kg}^{-1}$, shows low seasonal variability and decreasing values moving westward, as also pointed out by Alvarez et al. (2014). This layer is recharged by the high-alkalinity values and dense water that are generated in the Adriatic and Aegean seas and subsequently deepens in the Levantine and Ionian sub-basins. 

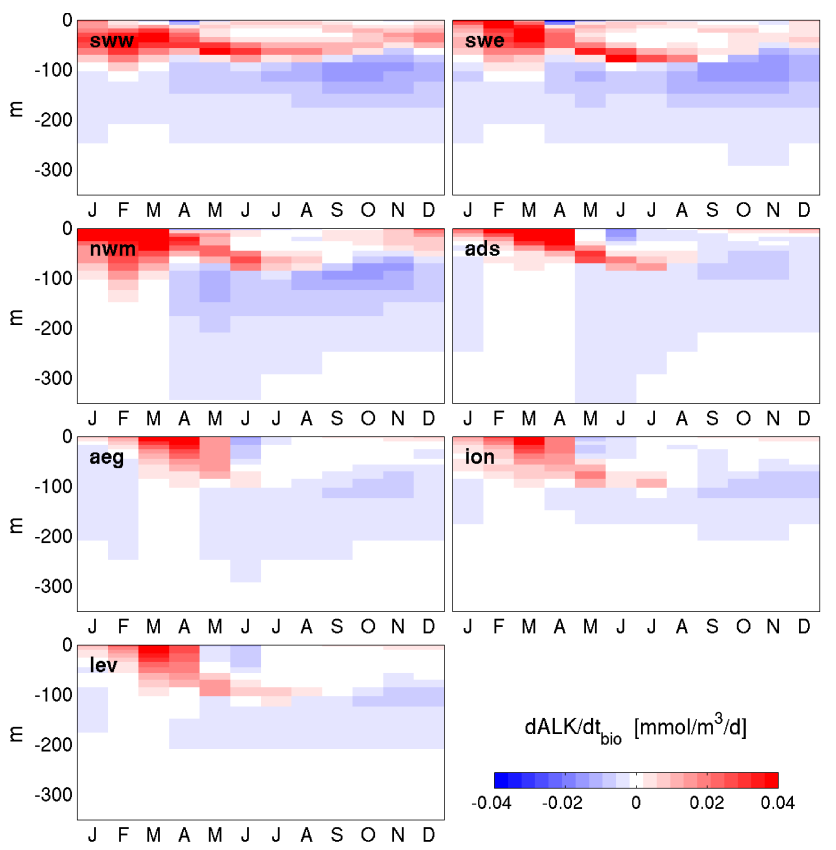

Figure 7. Annual evolution of the mean sub-basin average vertical profiles of the biological term of $\frac{\partial A L K}{\partial t}$ equation. Monthly values are averaged considering only areas deeper than $200 \mathrm{~m}$.

In the Levantine and Ionian sub-basins, the seasonal cycle of summer evaporation and winter mixing produces large excursions at the surface (up to $40-45 \mu \mathrm{mol} \mathrm{kg}{ }^{-1}$ ) and a mean seasonal variability of more than $30 \mu \mathrm{mol} \mathrm{kg}{ }^{-1}$ in the first 50-100 m (Figs. 5 and 6h).

\subsection{Impacts of biological and physical processes on alkalinity variability}

According to the synthetic equation (Eq. 1), Figs. 7 and 8 report the mean annual cycle of the monthly rate of variation of alkalinity due to biological and physical (transport plus evaporation minus precipitation) processes for the selected sub-basins. The contribution of evaporation minus precipitation is added to the physical plots in Fig. 8.

The physical contribution is a factor of 5-8 times greater than the biological one, however in the surface layers of the water column, biological processes significantly contribute to the annual variability (Fig. 7) by increasing alkalinity during winter-spring period. The largest impact of biology is in the nwm region whereas eastern sub-basins are less impacted (Fig. 7). The high rate of plankton production causes a large uptake of $\mathrm{NO}_{3}^{-}$and $\mathrm{PO}_{4}^{3-}$ (which exceeds the $\mathrm{NH}_{4}^{+}$uptake) during the first half of the year, triggering an increase of alkalinity that can be higher than $0.04 \mathrm{mmol} \mathrm{m}^{-3} \mathrm{~d}^{-1}$ in the first $50-100 \mathrm{~m}$ of the water column. During summer, the productivity decreases (Lazzari et al., 2012), and in the layer below $100-120 \mathrm{~m}$, the mineralization of $\mathrm{NO}_{3}^{-}$(through processes of mineralization of $\mathrm{NH}_{4}^{+}$and subsequent nitrification) and

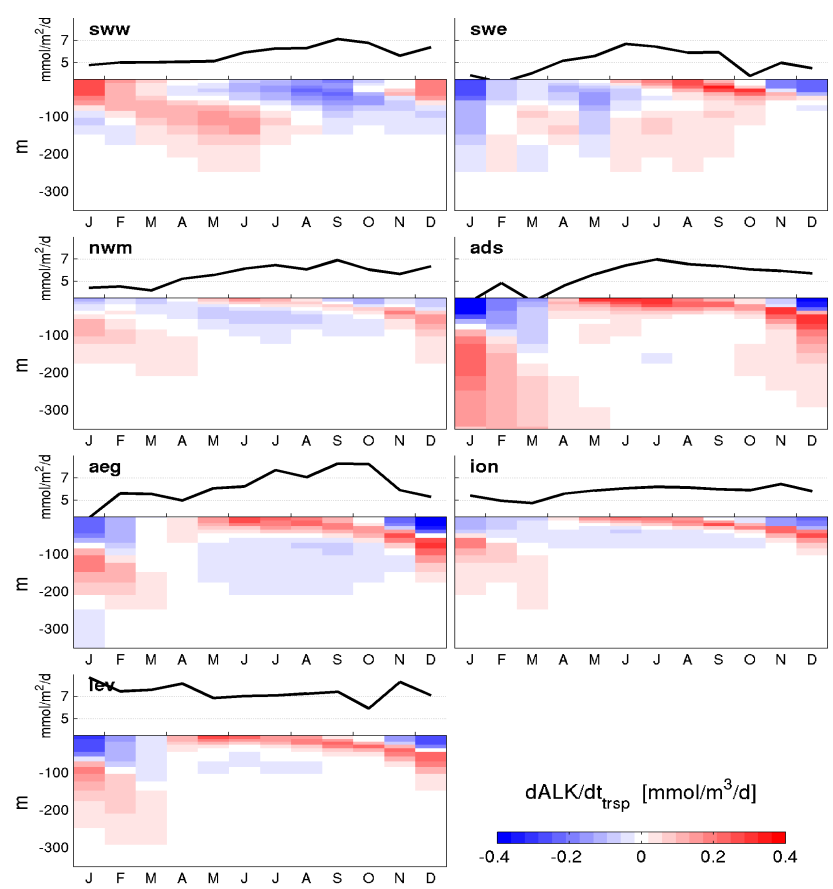

Figure 8. Annual evolution of the mean sub-basin average vertical profiles of the transport term of $\frac{\partial \mathrm{ALK}}{\partial t}$ equation (lower panels), and evolution of evaporation minus precipitation term (upper panels). Monthly values are averaged considering only areas deeper than $200 \mathrm{~m}$.

of $\mathrm{PO}_{4}^{3-}$ generally prevails. At these depths, biology contributes negatively to alkalinity throughout the year even if at lower rate (blue area in Fig. 7). The relevance of biological processes in contributing to the alkalinity dynamics decreases from the north-western to the eastern regions, according to the well-known decrease in the Mediterranean trophic gradient (Lazzari et al., 2012). The depth at which the positive impact of biology on alkalinity becomes zero increases eastward from $80-100$ to $120 \mathrm{~m}$ of the eastern sub-basins (Fig. 7), according to the deepening of the deep chlorophyll maximum from west to east (deep red spots in summer of plots of Fig. 7). This indicates that biology contributes to the high temporal variability of the surface values in the western sub-basins and that, together with physical processes, it contributes to the increase in alkalinity in the subsurface layer in the eastern sub-basins. Precipitation and dissolution of calcium carbonate should also be considered in the alkalinity biological equation. However, this process is poorly quantified for the Mediterranean Sea (only sparse measures of calcifiers abundances are available Siokou-Frangou et al., 2010; Oviedo et al., 2015) so it was not possible to include it in the model. Nevertheless, an offline estimate derived by combining information from global studies and models (Poulton et al., 2007; Gregg and Casey, 2007; Jansen et al., 2002), data on sedimentation (Stavrakakis et al., 2013) and our results indicates extra terms of the alkalinity budget up to 
$-0.007 \mathrm{mmol} \mathrm{m}^{-3} \mathrm{~d}^{-1}$ in the upper part of the water column and up to about $+0.004 \mathrm{mmol} \mathrm{m}^{-3} \mathrm{~d}^{-1}$ for the intermediate layer.

The term of surface evaporation minus precipitation, which is generally positive for the Mediterranean Sea, contributes to increasing the surface alkalinity, with an average rate that ranges from $6 \mathrm{mmol} \mathrm{m}^{-2} \mathrm{~d}^{-1}$ in the western sub-basins to $7 \mathrm{mmol} \mathrm{m}^{-2} \mathrm{~d}^{-1}$ in the eastern sub-basins (Fig. 8 upper panel). During summer, the increase of alkalinity due to the concentration process can reach values up to $0.3 \mathrm{mmol} \mathrm{m}^{-3} \mathrm{~d}^{-1}$ in the first $30-50 \mathrm{~m}$ (Fig. 8 lower panel). The autumn and winter vertical mixing drives a homogenization of the water column by decreasing surface values and increasing subsurface values. In the southern Adriatic Sea (ads) and Aegean Sea (aeg), these effects of recharging the deeper layers below 200-300 m are particularly visible during the autumn-winter vertical ventilation. The different pattern shown for the sww sub-region and partly for the swe sub-region is related to the impact of the lateral transport of low-alkaline water from the Atlantic that contrasts the increase due to evaporation at the surface.

An alkalinity budget is then compiled in order to quantify sources and sinks: the input from rivers and from the Dardanelles amount to $0.9 \times 10^{12} \mathrm{~mol} \mathrm{yr}^{-1}$ and $1.15 \times 10^{12} \mathrm{~mol} \mathrm{yr}^{-1}$, respectively. The simulated net flow at Gibraltar is an export of alkalinity equal to $3.1 \times 10^{12} \mathrm{~mol} \mathrm{yr}^{-1}$. Compared to the findings of Schneider et al. (2007), who estimated a net alkalinity outflow at Gibraltar of $0.8 \times 10^{12} \mathrm{~mol} \mathrm{yr}^{-1}$, our estimation is almost 4 times bigger and closer to the estimate of $2.43 \times 10^{12} \mathrm{~mol} \mathrm{yr}^{-1}$ given by Copin-Montègut (1993). Biological processes act as a source of alkalinity in the $0-100 \mathrm{~m}$ layer $\left(+0.52 \times 10^{12} \mathrm{~mol} \mathrm{yr}^{-1}\right)$ and as a sink of alkalinity in the intermediate and deep layers $\left(-0.47 \times 10^{12} \mathrm{~mol} \mathrm{yr}^{-1}\right)$. Therefore, a basin-scale budget of mass of proton acceptor compounds contributing to alkalinity sums up to an annual loss of about $1 \times 10^{12} \mathrm{~mol} \mathrm{yr}^{-1}$, equivalent to $0.3 \mathrm{~mol} \mathrm{~m}^{2} \mathrm{yr}^{-1}$ or - assuming that most processes are confined in the upper $300 \mathrm{~m}$ - to about $1 \mathrm{mmol} \mathrm{m}^{3} \mathrm{yr}^{-1}$, i.e. not too far from steady state.

\section{Conclusions}

In this paper, we used a calibrated state-of-the-art 3-D transport-biogeochemical-carbonate model to integrate the observations of alkalinity collected over the last decade into a single picture. The study returns a coherent picture of the spatiotemporal evolution of this parameter, which is crucial for properly assessing the impacts of ocean acidification.

Different factors (e.g. ingression of low-alkaline water from the Atlantic Ocean, surface concentrations due to evaporation in the eastern sub-basins and input from rivers and the Dardanelles) shape a basin-wide west-to-east gradient coupled with north-to-south gradients in the marginal seas (Adriatic and Aegean) and in the western sub-basin. As a consequence, the regression between salinity and alkalinity strongly varies from region to region and highlights that it is possible to use a single equation to reconstruct alkalinity values over the whole Mediterranean Sea only if marginal seas and regions of freshwater influence are not considered. The regression equations for each of these regions, treated separately, were also computed. A range up to $40 \mu \mathrm{mol} \mathrm{kg}^{-1}$ of the seasonal cycle should be considered typical at the surface in several parts of the Mediterranean Sea. Different processes trigger the alkalinity variability in different regions: seasonal cycles of summer concentration due to evaporation and winter vertical mixing in the eastern sub-basins, intense biological processes in the north-western sub-region and horizontal transport in the south-western sub-regions.

Acknowledgements. This study was supported by the EU projects MEDSEA (grant agreement no. 265103) and OPEC (grant agreement no. 283291).

Edited by: A. Shemesh

\section{References}

Álvarez, M., Sanleón-Bartolomé, H., Tanhua, T., Mintrop, L., Luchetta, A., Cantoni, C., Schroeder, K., and Civitarese, G.: The $\mathrm{CO}_{2}$ system in the Mediterranean Sea: a basin wide perspective, Ocean Sci., 10, 69-92, doi:10.5194/os-10-69-2014, 2014.

Artioli, Y., Blackford, J. C., Butenschon, M., Holt, J. T., Wakelin, S. L., Thomas, H., Borges, A. V., and Allen, J. I.: The carbonate system in the North Sea: sensitivity and model validation, J. Marine Syst., 102-104, 1-13, 2012.

Artuso, F., Chamard, P., Piacentino, S., Sferlazzo, D. M., De Silvestri, L., di Sarra, A., Meloni, D., and Monteleone, F.: Influence of transport and trends in atmospheric $\mathrm{CO}_{2}$ at Lampedusa, Atmos. Environ., 43, 3044-3051, 2009.

Bégovic, M. and Copin, C.: Alkalinity and pH measurements on water bottle samples during THALASSA cruise PROSOPE, doi:10.1594/PANGAEA.805265, 2013.

Béranger, K., Mortier, L., and Crèpon, M.: Seasonal variability of water transport through the Straits of Gibraltar, Sicily and Corsica, derived from a high-resolution model of the Mediterranean circulation, Prog. Oceanogr., 66, 341-364, 2005.

Brankart, J.-M. and Brasseur, P.: The general circulation in the Mediterranean Sea: a climatological approach, J. Marine Syst., 18, 41-70, 1998.

Copin-Montégut, C.: Alkaninity and carbon budgets in the Mediterranean, Global Biogeochem. Cy., 7, 915-925, 1993.

Copin-Montégut, C. and Bégovic, M.: Carbonate properties and oxygen concentrations at time series station DYFAME D, doi:10.1594/PANGAEA.738581, 2002.

Crise, A., Solidoro, C., and Tomini, I.: Preparation of initial conditions for the coupled model OGCM and initial parameters setting, MFSTEP report WP11, subtask 11310, 2003, 2003.

Dafner, E., Gonzalez-Davila, M., Santana-Casiano, J. M., and Sempere, R.: Total organic and inorganic carbon exchange through 
the Strait of Gibraltar in September 1997, Deep-Sea Res. Pt. I, 48, 1217-1235, 2001.

d'Ortenzio, F., Antoine, D., and Marullo, S.: Satellite-driven modeling of the upper ocean mixed layer and air-sea $\mathrm{CO}_{2}$ flux in the Mediterranean Sea, Deep-Sea Res. Pt. I, 55, 405-434, 2008.

Fiechter, J., Curchitser, E. N., Edwards, C. A., Chai, F., Goebel, N. L., and Chavez, F. P.: Air-sea $\mathrm{CO}_{2}$ fluxes on the California Current: impacts of model resolution and coastal topography, Global Biogeochem. Cy., 28, 371-385, 2014.

Gregg, W. W., Casey, N. W.: Modeling coccolithophores in the global oceans, Deep-Sea Res. Pt. II, 54, 447-477, 2007.

Huertas, I. E.: Hydrochemistry measured on water bottle samples during Al Amir Moulay Ab- dallah cruise CARBOGIB-1. Unidad de Tecnología Marina - Consejo Superior de Investigaciones Científicas, doi:10.1594/PANGAEA.618900, 2007a.

Huertas, I. E.: Hydrochemistry measured on water bottle samples during Garcia del Cid cruise GIFT-1. Unidad de Tecnología Marina - Consejo Superior de Investigaciones Científicas, doi:10.1594/PANGAEA.618916, 2007b.

Huertas, I. E., Ríos, A. F., García-Lafuente, J., Makaoui, A., Rodríguez-Gálvez, S., Sánchez-Román, A., Orbi, A., Ruíz, J., and Pérez, F. F.: Anthropogenic and natural $\mathrm{CO}_{2}$ exchange through the Strait of Gibraltar, Biogeosciences, 6, 647-662, doi:10.5194/bg-6-647-2009, 2009.

Jansen, H., Zeebe R., and Wolf-Gladrow, D.: Modelling the dissolution of settling $\mathrm{CaCO}_{3}$ in the ocean, Global Biogeochem. Cy., $16,1-16,2002$.

Lazzari, P., Teruzzi, A., Salon, S., Campagna, S., Calonaci, C., Colella, S., Tonani, M., and Crise, A.: Pre-operational short-term forecasts for Mediterranean Sea biogeochemistry, Ocean Sci., 6, 25-39, doi:10.5194/os-6-25-2010, 2010.

Lazzari, P., Solidoro, C., Ibello, V., Salon, S., Teruzzi, A., Béranger, K., Colella, S., and Crise, A.: Seasonal and inter-annual variability of plankton chlorophyll and primary production in the Mediterranean Sea: a modelling approach, Biogeosciences, 9, 217-233, doi:10.5194/bg-9-217-2012, 2012.

Lee, K., Tong, L. T., Millero, F. J., Sabine, C. L., Dickson, A. G., Goyet, C., Park, G.-H., Wanninkhof, R., Feely, R. A., and Key, R. M.: Global relationships of total alkalinity with salinity and temperature in surface waters of the world's oceans, Geophys. Res. Lett., 33, L19605, doi:10.1029/2006GL027207, 2006.

Louanchi, F., Boudjakdji, M., Nacef, L.: Decadal changes in surface carbon dioxide and related variables in the Mediterranean Sea as inferred from a coupled data-diagnostic model approach, ICES J. Mar. Sci., 66, 1538-1546, 2009.

Luchetta, A., Cantoni, C., and Catalano, G.: New observations of $\mathrm{CO}_{2}$-induced acidification in the northern Adriatic Sea over the last quarter century, Chem. Ecol., 26, 1-17, 2010.

Ludwig, W., Dumont, E., Meybeck, M., and Heussne, S.: River discharges of water and nutrients to the Mediterranean and Black Sea: major drivers for ecosystem changes during past and future decades?, Prog. Oceanogr., 80, 199-217, doi:10.1016/j.pocean.2009.02.001, 2009.

Melaku Canu, D., Ghermandi, A., Nunes, P.A.L.D., Cossarini, G., Lazzari, P., and Solidoro C.: Estimating the Value of Carbon Sequestration Ecosystem Services in the Mediterranean Sea: An Ecological Economics Approach, Global Environmental Change, doi:10.1016/j.gloenvcha.2015.02.008, 2015.
Orr, J. C., Najjar, R., Sabine, C. L., and Joos, F.: Abiotic HOWTO, Internal OCMIP Report, LSCE/CEA Saclay, Gifsur-Yvette, France, 1999.

Orr, J. C., Fabry, V. J., Aumont, O., Bopp, L., and Doney, S. C. Feely, R. A., Gnanadesikan, A., Gruber, N., Ishida, A., Joos, F., Key, R. M., Lindsay, K., Maier-Reimer, E., Matear, R., Monfray, P., Mouchet, A., Najjar, R. G., Plattner, G.-K., Rodgers, K. B., Sabine, C. L., Sarmiento, J. L., Schlitzer, R., Slater, R. D., Totterdell, I. J., Weirig, M.-F., Yamanaka, Y., and Yool, A.: Anthropogenic ocean acidification over the twenty-first century and its impact on calcifying organisms, Nature, 437, 681-686, 2005.

Oviedo, A., Ziveri, P., Álvarez, M., and Tanhua, T.: Is coccolithophore distribution in the Mediterranean Sea related to seawater carbonate chemistry?, Ocean Sci., 11, 13-32, doi:10.5194/os11-13-2015, 2015.

Palmiéri, J., Orr, J. C., Dutay, J.-C., Béranger, K., Schneider, A., Beuvier, J., and Somot, S.: Simulated anthropogenic CO2 uptake and acidification of the Mediterranean Sea, Biogeosciences Discuss., 11, 6461-6517, doi:10.5194/bgd-11-6461-2014, 2014.

Poulton, A. J., Adey, T. R., Balch, W. M., and Holligan, P. M: Relating coccolithophore calcification rates to phytoplankton community dynamics: regional differences and implications for carbon export, Deep-Sea Res. Pt. II, 54, 538-557, 2007.

Prowe, F. A. E., Thomas, H., Pätsch, J., Kühn, W., Bozec, Y., Schiettecatte, L.-S., Borges, A. V., and de Baar, H. J. W.: Mechanisms controlling the air-sea $\mathrm{CO}_{2}$ flux in the North Sea, Cont. Shelf. Res., 29, 1801-1808, 2009.

Ribera d'Alcalà, M., Civitarese, G., Conversano, F., and Lavezza, R.: Nutrient ratios and fluxes hint at overlooked processes in the Mediterranean Sea, J. Geophys. Res., 8, 8106, doi:10.1029/2002JC001650, 2003.

Rodrigues, L. C., van den Bergh, J. C. J. M., and Ghermandi, A.: Socio-economic impacts of ocean acidification in the Mediterranean Sea, Mar. Policy, 38, 447-456, 2013.

Santana-Casiano, J. M., Gonzalez-Davila, M., and Laglera, L. M.: The carbon dioxide system in the Strait of Gibraltar, Deep-Sea Res. Pt. II, 49, 4145-4161, 2002.

Schneider, A., Wallace, D. W. R., and Kortzinger, A.: The alkalinity of the Mediterranean Sea, Geophys. Res. Lett., 34, L15608, doi:10.1029/2006GL028842, 2007.

Siokou-Frangou, I., Christaki, U., Mazzocchi, M. G., Montresor, M., Ribera d'Alcalá, M., Vaqué, D., and Zingone, A.: Plankton in the open Mediterranean Sea: a review, Biogeosciences, 7, 15431586, doi:10.5194/bg-7-1543-2010, 2010.

Stavrakakis, S., Gogou, A., Krasakopoulou, E., Karageorgis, A. P., Kontoyiannis, H., Rousakis, G., Velaoras, D., Perivoliotis, L., Kambouri, G., Stavrakaki, I., and Lykousis, V.: Downward fluxes of sinking particulate matter in the deep Ionian Sea (NESTOR site), eastern Mediterranean: seasonal and interannual variability, Biogeosciences, 10, 7235-7254, doi:10.5194/bg-10-7235-2013, 2013.

Somot, S., Sevault, F., Déqué, M., and Crépon, M.: 21st century climate change scenario for the Mediterranean using a coupled atmosphere-ocean regional climate model, Global Planet. Change, 63, 112-126, 2008.

Takahashi, T., Sutherland, S. C., Chipman, D. W., Goddard, J. G., Ho, C., Newberger, T., Sweeney, C., and Munro, D. R.: Climatological distributions of $\mathrm{pH}, p \mathrm{CO}_{2}$, total $\mathrm{CO}_{2}$, alkalinity, and $\mathrm{CaCO} 3$ saturation in the global surface ocean, and tem- 
poral changes at selected locations, Mar. Chem., 164, 95-125, doi:10.1016/j.marchem.2014.06.004, 2014.

Tanhua, T., Alvarez, M., and Mintrop, L.: Carbon Dioxide, Hydrographic, and Chemical Data Obtained During the R/V Meteor MT84_3 Mediterranean Sea Cruise (April 5-April 28, 2011)., http://cdiac.ornl.gov/ftp/oceans/CLIVAR/Met_84_3_Med_Sea/. Carbon Dioxide Information Analysis Center, Oak Ridge National Laboratory, US Department of Energy, Oak Ridge, Tennessee, doi:10.3334/CDIAC/OTG.CLIVAR_06MT20110405, 2012.

Touratier, F. and Goyet, C.: Impact of the eastern Mediterranean Transient on the distribution of anthropogenic $\mathrm{CO}_{2}$ and first estimate of acidification fro the Mediterranean Sea, Deep-Sea Res. Pt. I, 58, 1-15, 2011.

Turi, G., Lachkar, Z., and Gruber, N.: Spatiotemporal variability and drivers of $p \mathrm{CO}_{2}$ and air-sea $\mathrm{CO}_{2}$ fluxes in the California Current System: an eddy-resolving modeling study, Biogeosciences, 11, 671-690, doi:10.5194/bg-11-671-2014, 2014.

Turley, C. and Boot, K.: The ocean acidification challenges facing science and society, in: Ocean Acidification, edited by: Gattuso, J.-P. and Hansson, L., Oxford University Press, 249-271, 2011.
Uppala, S. M., Kallberg, P. W., Simmons, A. J., Andrae, U., da Costa Bechtold, V., Fior- ino, M., Gibson, J. K., Haseler, J., Hernandez, A., Kelly, G. A., Li, X., Onogi, K., Saarinen, S., Sokka, N., Allan, R. P., Andersson, E., Arpe, K., Balmaseda, M. A., Beljaars, A. C. M., van de Berg, L., Bidlot, J., Bormann, N., Caires, S., Chevallier, F., Dethof, A., Dragosavac, M., Fisher, M., Fuentes, M., Hagemann, S., Holm, E., Hoskins, B. J., Isaksen, L., Janssen, P. A. E. M., Jenne, R., McNally, A. P., Mahfouf, J.-F., Morcrette, J.-J., Rayner, N. A., Saunders, R. W., Simon, P., Sterl, A., Trenberth, K. E., Untch, A., Vasiljevic, D., Viterbo, P., and Woollen, J.: The ERA-40 re-analysis, Q. J. Roy. Meteor. Soc., 131, 2961-3012, 2005.

Wakelin, S. L., Holt, J. T., Blackford, J. C., Allen, J. I., Butenschön, M., and Artioli, Y.: Modeling the carbon fluxes of the northwest European continental shelf: validation and budgets, J. Geophys. Res., 117, C05020, doi:10.1029/2011JC007402, 2012.

Wolf-Gladrow, D. A., Zeebe, R. E., Klaas, C., Körtzinger, A., and Dickson, A. G.: Total alkalinity: the explicit conservative expression and its application to biogeochemical processes, Mar. Chem., 106, 287-300, 2007.

Zeebe, R. E. and Wolf-Gladrow, D.: $\mathrm{CO}_{2}$ in Seawater: Equilibrium, Kinetics, Isotopes, Elsevier Oceanography Series, Elsevier, Amsterdam, the Netherlands, 2001. 